Niepełnosprawność. Dyskursy pedagogiki specjalnej

Nr 30/2018

Disability. Discourses of special education

No. 30/2018

Anna Bernacka

Uniwersytet Warmińsko-Mazurski w Olsztynie

\title{
Opinie społeczności holenderskiej dotyczące funkcjonowania Fundacji na Rzecz Kontaktów Alternatywnych (Suchting Alternative Relatiebemeideling, SAR) - raport z badań pilotażowych
}

W artykule przedstawiono wyniki badań pilotażowych przeprowadzonych w dwóch miastach holenderskich. W badaniach wykorzystano metodę sondażu diagnostycznego. Zastosowano kwestionariusz ankiety, który zawierał 11 pytań zamkniętych. Badanie dotyczyło opinii Holendrów na temat Fundacji Alternatywnych Kontaktów i jej działania. Wyniki badań wskazują na liberalne podejście do typu form wsparcia udzielanego osobom niepełnosprawnym. Holenderska społeczność wie o działaniu takiej organizacji oraz przyjmuje i akceptuje takie formy wsparcia dla życia intymnego ludzi z niepełnosprawnościami.

Słowa kluczowe: niepełnosprawność, seksualność, wsparcie

\section{Opinions of the Dutch community regarding the Foundation for Contacts Alternative (Suchting Alternative Relatiebemeideling, SAR) - a report from pilot studies}

The sexual revolution, which began in the late 1960s and early 1970s, has led to increased interest in the sexuality of people with disabilities. Researchers and practitioners have begun exploring the sexuality of this group with particular emphasis on support and assistance in this area. Western countries, much faster than the countries of the Eastern Bloc, have developed a number of social, systemic and legal solutions in this area. In the West, the law permits marriages of persons with disabilities, so that there are not only marriages that "consume" their relationship, but also the so-called. "White marriage". The solutions for the solitary were the ones created in the 1980s, organizations supporting the sexual sphere of people with disabilities. For example, in 1982 the Netherlands created Foundations for Alternative Contacts (Suchting Alternative Relatiebemeideling). This article presents the results of pilot studies conducted in two Dutch towns. The diagnostic survey method was used in the studies. A survey questionnaire was used, which contained 11 closed questions. The research concerned Dutch opinion on the Foundation for Alternative Contacts and its activities. The results of the research indicate a rather liberal approach to the type of intimate support provided to people with disabilities. The Dutch community knows about the workings of 
such an organization, and welcomes and accepts such forms of support for intimate life of people with disabilities.

Keywords: disability, sexuality, support

\section{Wprowadzenie}

Wolność seksualna jest podstawowym prawem każdego człowieka. Jej kwestie reguluje m.in. Powszechna Deklaracja Praw Seksualnych, która wyraźnie zwraca uwagę na wolność, równość i godność człowieka w kwestii jego seksualności. W Deklaracji czytamy: „Seksualność jest integralną częścią osobowości każdej istoty ludzkiej. Jej pełny rozwój zależy od zaspokojenia podstawowych ludzkich potrzeb, takich jak pragnienie obcowania, intymności, ekspresji uczuć, czułości i miłości" [Deklaracja Praw Seksualnych]. W myśl dokumentu każdy człowiek ma prawo do zaspokajania swoich potrzeb seksualnych zgodnie $\mathrm{z}$ własną wolą i sumieniem. Prawa do wyrażania swojej seksualności, w tym do prokreacji, reguluje Konwencja o Prawach Osób Niepełnosprawnych podpisana przez Polskę w 2007 r. W 2012 r. rząd polski ratyfikował Konwencję z zastrzeżeniem m.in. do art. 23, który dotyczy kwestii zawierania małżeństw przez osoby z niepełnosprawnością. W myśl polskiego kodeksu rodzinnego i opiekuńczego osoby z niepełnosprawnością intelektualną oraz chorobami psychicznymi nie mogą zawrzeć formalnego związku małżeńskiego [Konwencja o Prawach Osób Niepełnosprawnych].

Rewolucja seksualna, która została zapoczątkowana na przełomie lat 60. i 70. XX w. w znacznej mierze przyczyniła się do odkrycia "na nowo" seksualności człowieka, w tym człowieka z niepełnosprawnością. Zaczęto dostrzegać nie tylko znaczenie edukacji seksualnej, która, jak słusznie twierdzi E. Drozd, „nie stanowi żadnej specyficznej i odrębnej części wychowania" [Drozd 2010: 119], ale również pojawiły się głosy nawołujące i postulujące rozwiązanie kwestii zaspokajania potrzeb seksualnych przez osoby niepełnosprawne. Teoretycy i praktycy zaczęli zastanawiać się nad formami pomocy i wsparcia w aspekcie życia intymnego osób niepełnosprawnych. Wśród osób z głębszą niepełnosprawnością intelektualną funkcjonują tzw. małżeństwa chronione czy małżeństwa białe. Małżeństwa chronione stanowią element szerszej koncepcji określanej jako życie wspierane (supported living).

Takie związki funkcjonują w kilku krajach Europy m.in. w Belgii, Niemczech, Austrii, Danii, Holandii czy Szwecji [Parchomiuk 2016: 144]. W odrębnej sytuacji znajdują się osoby samotne, nieposiadające partnera życiowego i dzieci. W wielu krajach zachodniej Europy (m.in. Niemcy, Belgia, Holandia) pod koniec lat 70. i na początku lat 80 . XX w. zaczęto realizować nowe pomysły i rozwiązania dotyczące 
terapii i wsparcia seksualnego dorosłych osób niepełnosprawnych. W Niemczech centra doradztwa zawodowego oferują osobom chcącym się wyrwać z prostytucji przekwalifikowanie na pewnego rodzaju pracowników pomocy społecznej. Tacy pracownicy świadczyliby usługi seksualne osobom niepełnosprawnym. W Holandii z kolei funkcjonują organizacje świadczące usługi osobom niepełnosprawnym. Jedną z nich jest Fundacja na Rzecz Kontaktów Alternatywnych. Obszar związany ze świadczeniem usług seksualnych osobom z niepełnosprawnością może ewokować występowanie problemów etycznych, których konsekwencje mogą być trudniejsze do przeżycia dla osoby z niepełnosprawnością.

Fundacja na Rzecz Kontaktów Alternatywnych to organizacja, która organizuje "seks spotkania” osobom z fizyczną i intelektualną niepełnosprawnością. Fundacja jest niewielką organizacją zatrudniającą ok 30 osób (kobiet i mężczyzn), świadczących usługi seksualne osobom z niepełnosprawnością. Ma również aktywnych działaczy w Belgii oraz Niemczech [http://www.stichtingsar.nl/EN_index.html].

Fundacja została założona z inicjatywy niepełnosprawnego mężczyzny w 1982 r. Organizacja zatrudnia osoby pełnosprawne, które świadczą usługi seksualne osobom niepełnosprawnym w ich miejscu zamieszkania. Działalność SAR dotuje rząd oraz ośrodki zdrowia. Państwo refunduje niepełnosprawnym dwa spotkania miesięcznie, resztę spotkań refundują ośrodki zdrowia. Z usług fundacji korzystają osoby niepełnosprawne samotne, bądź będące w związkach. $\mathrm{W}$ przypadku, kiedy osoby niepełnosprawne są w związkach, konieczna jest zgoda partnera życiowego [http://www.stichtingsar.nl/EN_index.html].

W 1999 r. taką formą terapii w Holandii objętych było 1300 osób. Osobami, które świadczą usługi seksualne niepełnosprawnym są zarówno kobiety, jak i mężczyźni w wieku od 25 do 60 lat. Są to osoby żyjące samotnie lub w związkach. W przypadku kiedy pracownik SAR jest w związku, konieczna jest zgoda partnera życiowego [Loebl, Nowak-Lipińska 2002: 85].

Bardzo ważnym aspektem działalności pracowników SAR jest profesjonalizacja ich usług. Pracownik SAR nie może tylko posiadać umiejętności pielęgniarskich, musi przestrzegać nieprzekraczania granic emocjonalnych. W sytuacji kiedy pojawi się uczucie z jakiejkolwiek strony, natychmiast przerywany jest kontakt. Niepełnosprawni mężczyźni bywają często bardzo zadowoleni, gdyż wprowadza to w ich życie urozmaicenie. Panowie koncentrują się głównie na fizycznych doznaniach. Kobiety odczuwają nieco inaczej. Autorka przytoczyła wypowiedz pewnego mężczyzny - pracownika SAR: „Pewna kobieta zakochała się we mnie, a że nie jest to sytuacja, w której mógłbym pracować (regulaminowy zakaz), trzeba było się wycofać. Nie chciała nikogo innego". Ze względu na różne preferencje i upodobania seksualne niektórych mężczyzn istnieje możliwość korzystania z usług agencji towarzyskiej. Koszt takich spotkań jest jednak wyższy ze względu na odrazę jaką budzą niektórzy klienci [Loebl, Nowak-Lipińska 2002: 
85-86]. Wszelkie informacje na temat fundacji można znaleźć na stronie internetowej, bądź uzyskać osobiście, dzwoniąc pod wskazany na stronie numer telefonu.

\section{Założenia metodologiczne}

Celem niniejszych badań było ustalenie opinii dorosłych mieszkańców dwóch małych holenderskich miejscowości, na temat różnych form wsparcia w sferze intymnej na przykładzie Fundacji na Rzecz Kontaktów Alternatywnych. Podmiotem badawczym była holenderska społeczność. Przedmiot badań stanowiły opinie społeczności holenderskiej dotyczące funkcjonowania Fundacji na Rzecz Kontaktów Alternatywnych.

Sformułowano następujący problem główny: Jakie deklaracje na temat Fundacji na Rzecz Kontaktów Alternatywnych prezentują dorośli Holendrzy?

Problemy szczegółowe brzmią następująco:

- Jakie informacje respondenci posiadają na temat Fundacji na Rzecz Kontaktów Alternatywnych?

- Jakie osoby z niepełnosprawnością, zdaniem badanych, powinny korzystać z usług Fundacji na Rzecz Kontaktów Alternatywnych?

- Jaka forma wsparcia instytucjonalnego w sferze intymnej/seksualnej zdaniem badanych jest odpowiednia dla osób z niepełnosprawnością?

- Jakie trudności zdaniem badanych respondentów mogą napotkać osoby z niepełnosprawnością korzystające z usług pracowników Fundacji na Recz Kontaktów Alternatywnych?

- Na jakie trudności zdaniem badanych mogą napotkać osoby pracujące w fundacji i świadczące usługi seksualne osobom niepełnosprawnym?

- Osoby z jakimi typami niepełnosprawności zdaniem badanych powinny korzystać z usług?

- Jak badani reagowaliby na chęć skorzystania z usług świadczonych przez fundację przez ich niepełnosprawne dzieci, gdyby wychowywali niepełnosprawne dziecko?

- Ile spotkań z pracownikiem fundacji w ciągu miesiąca zdaniem badanych Państwo powinno refundować?

- Jakie zdaniem badanych jest podejście rodziców i najbliższych znajomych osób z niepełnosprawnością do tego typu usług?

Badania zostały przeprowadzone w strategii ilościowej. Zastosowano metodę sondażu diagnostycznego. Posłużono się kwestionariuszem ankiety, która składała się 11 pytań zamkniętych. Ankieta została przetłumaczona na język holenderski przez tłumacza oraz rozdana pięćdziesięciu dorosłym osobom - rodowitym Holendrom, kobietom i mężczyznom w przedziale wiekowym 33-63. 52,3\% badanej 
grupy stanowiły kobiety, natomiast 47,6\% grupy badanych stanowili mężczyźni. Osoby samotne nieposiadające partnera stanowiły $20 \%$ badanych osób, natomiast osoby będące w związku formalnym - $80 \%$. Żadna z badanych osób nie wychowywała i nie wychowuje dziecka $\mathrm{z}$ niepełnosprawnością. Wszyscy badani zadeklarowali, że w przeszłości mieli kontakt z osobami z niepełnosprawnością. Ankietę wypełniło i zwróciły 42 osoby. Dobór badanych był celowy. Ze względu na dobre relacje badacza z częścią badanych osób, zastosowano metodę kuli śnieżnej. Ankiety znajomi badacza rozdawali swoim znajomym. Kryterium doboru próby stanowił wiek osób badanych (osoby dorosłe) oraz brak dziecka z niepełnosprawnością. Taki dobór próby miał ukazać szersze pole widzenia różnych form wsparcia osób z niepełnosprawnością w życiu seksualnym, w perspektywie osób, które nie wychowują dziecka niepełnosprawnego.

Ankiety rozdano w dwóch holenderskich miejscowościach: Eerbeek oraz Deventer. Badania prowadzono na przełomie lipca i sierpnia 2014 r. Miały one charakter badań pilotażowych. Zmiennymi zależnymi są deklaracje badanych na temat Fundacji na Rzecz Kontaktów Alternatywnych, a więc: znajomość fundacji, formy wsparcia instytucjonalnego w sferze intymnej odpowiednie dla osób z niepełnosprawnością, trudności napotykane przez osoby z niepełnosprawnością korzystające z takich usług, grupy osób sięgające po taką formę wsparcia, reakcja rodziców na informację o chęci skorzystania z usług przez ich dzieci, częstotliwość spotkań oraz podejście rodziców i znajomych osób z niepełnosprawnością do korzystania z takich usług. Wskaźnikami tej zmiennej były poszczególne pytania $\mathrm{w}$ kwestionariuszu ankiety. $\mathrm{W}$ badaniach nie uwzględniono zmiennych niezależnych, takich jak: staż pracy, wiek badanych czy miejsce zamieszkania, gdyż badania miały charakter pilotażowy i celem ich było rozpoznanie ogólnego spojrzenia na kwestię opinii badanych. Badania planuję poszerzyć w najbliższym czasie. Wyniki zaprezentuję $\mathrm{w}$ postaci danych procentowych bez zestawiania ich $\mathrm{w}$ tabelach.

\section{Wyniki badań}

Zdecydowana większość badanych respondentów (96\%, 40 osób) zna i wie czym się zajmuje Fundacja na Rzecz Kontaktów Alternatywnych. Badani wiedzą, że fundacja poszukuje i zatrudnia osoby pełnosprawne, które po odbyciu szkoleń i wdrożeniu się w działanie, świadczą usługi seksualne osobom z niepełnosprawnością. Zdaniem badanych (55\%, 23 osoby) samotne osoby z niepełnosprawnością, znające zasady funkcjonowania takich fundacji, powinny korzystać z usług pracowników fundacji. Respondenci (45\%, 18 osób) uważają, że niepełnosprawne osoby będące w związkach, które wiedzą czym zajmują się fundacje świadczące usługi seksualne, nie powinny korzystać z usług pracowników organizacji, 25\% 
(10 osób) uważa, że pomimo związku osoby te powinny korzystać z usług pracowników fundacji, jeśli mają taką potrzebę i czują się osamotnione, natomiast $30 \%$ (12 osób) badanych nie miało zdania na ten temat.

Większość badanych respondentów $(65 \%, 27$ osób) uważa, że najlepszą instytucjonalną formą wsparcia w sferze seksualnej dla osób z niepełnosprawnością są fundacje i stowarzyszenia, które świadczą usługi seksualne bądź pomagają znaleźć partnera osobom niepełnosprawnym, "niestosowną" $\mathrm{i}$ „niemoralną" w ich przekonaniu formą są domy towarzyskie ( $25 \%, 10$ osób). $10 \%$ (4 osoby) badanych nie wypowiedziało się na ten temat. Zdaniem badanych (55\%, 23 osoby) najczęstszą trudnością, jaką mogą napotkać osoby z niepełnosprawnością korzystające z usług fundacji, są trudności natury psychicznej (osobowościowej), wyrażające się w poczuciu wstydu i zażenowania, 35\% (14 osób) uważa, że osoby te mogą mieć problem z komunikacją werbalną, co może wpłynąć na problemy z wyrażeniem swoich potrzeb, 10\% (4 osoby) uważa, że problem może tkwić $\mathrm{w}$ podejściu pracownika fundacji, który nieumiejętnie i niefachowo zajmie się osobą z niepełnosprawnością. Zdaniem badanych $(60 \%, 25$ osób) osoby pracujące w fundacji najczęściej mogą napotkać na trudność wynikającą z problemów w komunikacji z osobami niepełnosprawnymi, może to skutkować trudnościami w rozpoznaniu potrzeb, 30\% (12 osób) uważa, że pracownicy fundacji mogą napotkać barierę psychiczną u osób korzystających z usług, wynikającą z uczucia wstydu i zażenowania, 10\% (4 osoby) sądzi, że problemem może stać się emocjonalne przywiązanie do pracownika SAR. Zdaniem większości badanych $65 \%$, 27 osób), głównie osoby z niepełnosprawnością ruchową, powinny korzystać z usług fundacji, 25\% (10 osób) sądzi, że osoby z niepełnosprawnością sensoryczną mają prawo do korzystania z tego typu usług, natomiast $5 \%$ ( 2 osoby) uważa, że osoby z niepełnosprawnością intelektualną i z zaburzeniami psychicznymi mają prawo do korzystania z usług pracowników fundacji.

Zapytano również o reakcje respondentów, gdyby dowiedzieli się, że ich niepełnosprawne dziecko chciałoby skorzystać z takiej usługi. Wyniki są zaskakujące. Okazuje się, że 76\% (31 osób) rodziców nie wyraziłoby zgody na to, by ich dziecko skorzystało z usług fundacji. Tylko 14\% (5 osób) zgodziłby się na taką formę wsparcia, pod warunkiem, że podczas spotkań nie dojdzie do stosunku płciowego, $10 \%$ absolutnie nie zgodziłoby się na to, by ich dziecko realizowało swoje potrzeby seksualne $\mathrm{w}$ takiej formie.

Ustosunkowując się do pytania dotyczącego refundacji spotkań z pracownikami SAR większość badanych $(70 \%, 29$ osób) uważa, że tylko jedno spotkanie w ciągu miesiąca powinno być refundowane przez państwo. $20 \%$ (8 osób) badanych uważa, że dwa spotkania (tak jak jest prawnie ustanowione) powinny być refundowane. 10\% (4 osoby) jest za tym, aby trzy spotkania z pracownikiem fundacji finansowało państwo. 
Jednym z ostatnich problemów badawczych jest opinia badanych na temat podejścia rodziców osób z niepełnosprawnością, do kwestii związanych z zaspokajaniem potrzeb seksualnych, przez pracowników fundacji świadczących usługi seksualne. Większość uważa ( $80 \%, 33$ osoby), że rodzina osoby z niepełnosprawnością nie powinna godzić się na takie formy "terapii” ich dzieci. 15\% (6 osób) badanych jest zdania, że rodzina powinna zaakceptować decyzję dziecka z niepełnosprawnością i wspierać go w każdej sytuacji, 5\% (2 osoby) sądzi, że rodzice i rodzina nie powinni ingerować $\mathrm{w}$ życie osoby $\mathrm{z}$ niepełnosprawnością. Zdaniem respondentów $(64 \%$, 26 osób) znajomi osób z niepełnosprawnością powinni akceptować decyzję kolegi/koleżanki z niepełnosprawnością, 26\% (10 osób) badanych uważa, że znajomi nie powinni akceptować tego typu zachowań, 10\% (4 osoby) jest zdania, że znajomi nie powinni ingerować w życie seksualne niepełnosprawnego kolegi/koleżanki.

\section{Wnioski z badań i refleksje}

Holandia jest państwem liberalnym w stosunku do kwestii rozwiązań systemowych, społecznych, prawnych, dotyczących wsparcia i pomocy osobom niepełnosprawnym, również w sferze ich seksualności. Wyniki badań pilotażowych wyraźnie wskazują na postawę liberalną w tym zakresie. Okazuje się, że Holendrzy uczestniczący w badaniu wiedzą czym się zajmuje ta fundacja. Jest to zaskakujące, gdyż jest to niewielka organizacja, skupiająca ok. 30 pracowników, jednak o dosyć dużym zasięgu terytorialnym, bo obejmująca osoby z niepełnosprawnością w całym kraju i za granicą. Przypuszczać można, że badani wiedzą również o innych organizacjach wspierających seksualność osób niepełnosprawnych. Co ciekawe, większość badanych uważa, że osoby niepełnosprawne, które są samotne powinny korzystać z usług takiej fundacji. Aż 25\% (10 osób) badanych uważa, że osoby niepełnosprawne będące $w$ związkach, jeśli mają taką potrzebę powinny korzystać z usług oferowanych przez organizacje. Większość badanych uważa, że taka forma pomocy jest jak najbardziej odpowiednia dla osób z niepełnosprawnością. $25 \%$ (10 osób) neguje korzystanie z usług prostytutek w domach publicznych przez osoby z niepełnosprawnością. Jest to dosyć wysoki wskaźnik biorąc pod uwagę fakt, że w Holandii od 2000 roku prostytucja w zorganizowanych formach (domy publiczne, sekskluby) jest legalna. Większość badanych uważa, że najczęstszą trudnością, jaką mogą napotkać osoby z niepełnosprawnością korzystające $\mathrm{z}$ usług fundacji, są trudności związane $\mathrm{z}$ sferą psychiczną przejawiające się w uczuciach wstydu i zażenowania. Z kolei osoby świadczące usługi seksualne mogą napotkać trudność wynikającą z problemów w komunikacji z osobami niepełnosprawnymi, co może skutkować trudnościami w rozpoznaniu po- 
trzeb. Badani uważają, że osoby z niepełnosprawnością ruchową głównie powinny korzystać z usług fundacji. Najmniej osób opowiedziało się za tym, by osoby z niepełnosprawnością intelektualną i zaburzeniami psychicznymi mogły skorzystać z usług fundacji. Wyniki tej zmiennej można porównać do badań Z. Izdebskiego oraz M. Parchomiuk. Badania Z. Izdebskiego dotyczyły postaw Polaków wobec seksualności osób z niepełnosprawnością ruchową i intelektualną. Wyniki tych badań pokazują, że Polacy częściej wykazują pozytywne postawy wobec seksualności osób z niepełnosprawnością ruchową (częściej godzą się na zawarcie przez takie osoby związku małżeńskiego, posiadania potomstwa) [Izdebski 2005: 35-36]. Eksploracje badawcze M. Parchomiuk dotyczyły postaw specjalistów (pedagogów specjalnych i pedagogów) wobec seksualności osób z niepełnosprawnością intelektualną (stopień lekki i głębsze). Specjaliści z grupy podstawowej, jak i kontrolnej wykazują przychylniejsze postawy wobec osób z lekką niepełnosprawnością intelektualną [Parchomiuk 2013: 210].

Zdaniem badanych rodzice nie powinni akceptować takich form zaspokajania potrzeb seksualnych przez swoje niepełnosprawne dzieci. Społeczność holenderska podobnie jak polska, dba o dobro swoich dzieci. Można przypuszczać, że Holendrzy chcieliby, aby ich dzieci tworzyły dłuższe relacje z partnerami, które nasycone będą miłością i zaufaniem. Rodzice coraz częściej akceptują i wspierają seksualność swoich dzieci. Poszukują informacji, współpracują ze specjalistami: nauczycielami, terapeutami. Analizując badania [Huszcz 1999; Giryński 2005; Karwacka 2005; Drummond 2006; Swango-Wilson 2009; Kijak 2014] w kwestii postaw rodziców, opiekunów, nauczycieli wobec seksualności niepełnosprawnych dzieci i młodzieży można zauważyć pewną tendencję, która z każdą dekadą zmierza ku postawom akceptacji i zrozumienia potrzeb seksualnych.

Seksualność osób niepełnosprawnych przestała być tematem tabu, czego potwierdzeniem są liczne doniesienia badawcze na gruncie polskim i zagranicznym. Na dzień dzisiejszy nie ma perspektyw, by rozwiązania krajów zachodnich, chociaż w małym zakresie zaadaptować do polskich warunków. Zwolennicy liberalnego podejścia do seksualności osób z niepełnosprawnością (zwolennicy orientacji seksualno-totalno-akceptującej) są pozytywnie nastawieni do tego typu rozwiązań. Przeciwnicy (zwolennicy orientacji deseksualizacyjno-unikającej) uważają, że tego typu działania mogą przyczynić się do rozerotyzowania tej grupy osób [Nowak-Lipińska 2002: 193-203].

\section{Bibliografia}

Drozd E. (2010), Problem edukacji seksualnej młodzieży niepetnosprawnej intelektualnie [w:] Edukacyjne i rehabilitacyjne konteksty rozwoju osób z niepełnosprawnościa w różnych okresach ich życia, Z. Palak (red.), Wydawnictwo UMCS, Lublin. 
Drummond E. (2006), Attitudes towards sexuality: A pilot study in Ireland, „Learning Disability Practise, vol. 9(4), s. 28-34.

Fundacja na Rzecz Kontaktów Alternatywnych, http://www.stichtingsar.nl/EN_index. html [dostęp: 25.05.2014].

Giryński A. (2005), Edukacja seksualna osób niepetnosprawnych intelektualnie w świetle opinii rodziców i nauczycieli [w:] Seksualność osób z niepetnosprawnościa intelektualną. Uwalnianie od schematów i uprzedzeń, J. Głodkowska, A. Giryński (red.), Wydawnictwo APS, Warszawa.

Huszcz, M. (1999), Wychowanie seksualne dzieci specjalnej troski w młodszym wieku szkolnym, Wydawnictwo WARS, Warszawa.

Izdebski Z. (2005), Postawy Polaków wobec seksualności osób niepetnosprawnych ruchowo i intelektualnie [w:] Seksualność osób z niepetnosprawnościa intelektualną. Uwalnianie od schematów i uprzedzeń, red. J. Głodkowskiej, A. Giryński, Wydawnictwo APS, Warszawa.

Karwacka M. (2005), Rodzice wobec seksualności dziecka niepetnosprawnego [w:] Seksualność osób z niepetnosprawnościa intelektualną. Uwalnianie od schematów i uprzedzeń, J. Głodkowskiej, A. Giryński (red.), Wydawnictwo APS, Warszawa.

Kijak R. (2014), Seksualność człowieka z niepetnosprawnościa intelektualną a rodzina, PWN, Warszawa.

Konwencja o Prawach Osób Niepełnosprawnych, https://www.rpo.gov.pl/p1/konwencja-o-prawach-osob-niepelnosprawnych [dostęp 27.09.2017].

Loebl W., Nowak - Lipińska K. (2002), Fatamorgana" wysp szczęśliwych", czyli o realizacji ptciowości osób niepetnosprawnych fizycznie [w:] Dyskursy pedagogiki specjalnej. Od tradycjonalizmu do ponowoczesności, E. Górniewicz, A. Krause (red.), Wydawnictwo UWM, Olsztyn.

Parchomiuk M. (2013), Postawy pedagogów specjalnych wobec seksualności osób z niepełnosprawnościq intelektualna, Wydawnictwo UMCS, Lublin.

Parchomiuk M. (2016), Seksualność człowieka z niepetnosprawnością intelektualną, Oficyna Wydawnicza „Impuls”, Kraków.

Powszechna Deklaracja Praw Seksualnych, http://www.heal.pl/pliki/DeklaracjaPraw Seks.pdf [dostęp:27.09.2017].

Swago-Wilson A. (2009), Perception of sex education for individuals with developmental and cognitive disability: A four cohort study, "Sexuality and disability”, vol. 27(4), s. 223-228. 